IRSTI 06.51 .51

\author{
Myrzahmetova Aida ${ }^{1}$, Syan $\mathbf{G i}^{2}$ \\ ${ }^{1}$ Candidate of Economic Sciences, Associate Professor of \\ the Department of International Relations and World Economy, Faculty of International Relations, \\ al-Farabi Kazakh National University, Almaty, Kazakhstan, \\ e-mail: aidam201167@gmail.com, tel.:+7 7079225678 \\ ${ }^{2} 1$ st year student of the master's program, specialty World Economy, \\ Department of International Relations and World Economy, Faculty of International Relations, \\ al-Farabi Kazakh National University, Almaty, Kazakhstan, China, \\ e-mail: 384679269@gg.com, tel.: +7 7757628297
}

\title{
TRANSIT POTENTIAL OF KAZAKHSTAN IN THE SILK ROAD ECONOMIC BELT
}

This article is devoted to the analysis of Kazakhstan's transit potential in the Silk Road Economic Belt. The transit potential of the country is part of the market infrastructure that must be developed for the successful functioning of the entire economy of the country. Kazakhstan is one of the largest countries in the world that has no access to the sea, but it has the capacity and should develop its transit and transport potential. The author studies opportunities, problems and benefits of the country from use of the transit potential, shows the real need for its effective realization. In conditions of globalization of world economy transit becomes the most important condition for country's active participation in the international trade, a factor of development of transport branch and a source of replenishment of the state budget. Effective realization of transit potential of the RK in the international transport system is promoted by the international transport corridors passing through the territory of the country diversely. Important advantage of transit through the RK territory is the stable political situation and favorable investment climate. Nowadays, transit potential of Kazakhstan is not involved fully.

Key words: transit potential, transport corridors, Eurasian integration, international trade. China's initiative, the economic belt of the Silk Road is a project that enables Kazakhstan to become a full participant in international transportation at the present time.

Мырзахметова Аида' ${ }^{1}$ Сян Ажи²

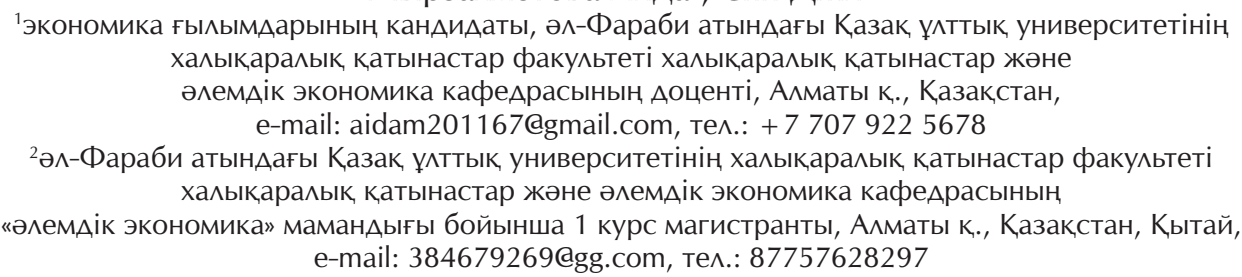

Жібек жолының Экономикалық белдеудегі Қазақстанның транзиттік әлеуеті

Аталған мақала Жібек жолының Экономикалық белдеудегі Қазақстанның транзиттік әлеуетін талдауға арналған. Елдің транзиттік әлеуеті бүкіл экономиканың табысты жұмыс істеуі үшін әзірленген қажет нарықтық инфрақұрылымның бір бөлігі болып табылады. Қазақстан теңізге шығу жолы жоқ, ол әлемлегі ең ірі елдердің бірі болып табылады, бірақ қабілеті бар және оның транзиттік және көліктік әлеуетін дамыту керек. Автор елдің транзиттік әлеуетін пайдалану мүмкіндіктерін, мәселелері мен ұтымдарын зерделей отырып, оны тиімді жүзеге асыру қажеттілігін көрсетеді. Әлемдік экономиканың жаһандануы жағдайында транзит елАің халықаралық, саудаға белсенді қатысуының маңызды шарты, көлік саласын дамытудың факторы мен мемлекеттік бюджетті толтырудың қайнар көзі болып табылады. Халықаралық көлік жүйесінде ҚР-дың транзит- 
тік әлеуетін тиімді жүзеге асыруға әр түрлі бағыттарға ел аумағы арқылы өтетін көлік дәліздері мүмкіндік береді. ҚР аумағы арқылы транзиттің маңызды артықшылығы тұрақты саяси жағдай мен қолайлы инвестициялық климат болып табылады. Қазіргі уақытта Қазақстанның транзиттік әлеуеті толық көлемде іске қосылмаған. Жибек жолы Экономикалық белдеу Қытайдың бастамасы - Қазақстанға қазіргі уақытта халықаралық тасыма^дау толыққанды мүшесі болуға мүмкіндік беретін жоба.

Түйін сөздер: транзиттік әлеует, көлік дәліздері, еуразиялық интеграция, халықаралық, сауда.

$$
\begin{aligned}
& \text { Мырзахметова Аида }{ }^{1}, \text { Сян Ажи }{ }^{2} \\
& { }^{1} \text { кандидат экономических наук, доцент кафедры международных отношений и } \\
& \text { мировой экономики факультета межАународных отношений } \\
& \text { Казахского национального университета имени а^ь-Фараби, г. А^маты, Казахстан, } \\
& \text { e-mail: aidam201167@gmail.com, тел.: + } 77079225678 \\
& { }^{2} \text { магистрант } 1 \text { курса специальности «Мировая экономика» кафедры международных отношений и } \\
& \text { мировой экономики факультета межАународных отношений } \\
& \text { Казахского национального университета им. аль-Фараби. г. Алматы, Казахстан, КНР, } \\
& \text { e-mail: 384679269@gg.com, тел.: + } 77757628297
\end{aligned}
$$

\begin{abstract}
Эта статья посвящена анализу транзитного потенциала Казахстана в Экономическом Поясе Шелкового пути. Транзитный потенциал страны является частью рыночной инфраструктуры, которую необходимо развивать Аля успешного функционирования всей экономики страны. Казахстан является одной из самых крупных стран мира, не имеющих выхода к морю, но имеет возможности и должен развивать свой транзитный и транспортный потенциал. Автор изучает возможности, проблемы и выгоды страны от использования своего транзитного потенциала, показывает необходимость его эффективной реализации. В условиях глобализации мировой экономики транзит становится важнейшим условием активного участия страны в международной торговле, фактором развития транспортной отрасли и источником пополнения государственного бюджета. Эффрективной реализации транзитного потенциала РК в межАународной транспортной системе способствуют международные транспортные коридоры, проходящие через территорию страны в разных направлениях. Важным преимуществом транзита через территорию РК является стабильная политическая ситуация и благоприятный инвестиционный климат. В настоящее время транзитный потенциал Казахстана не задействован в полной мере. Инициатива Китая Экономический пояс Шелкового пути - это проект, который дает возможность Казахстану стать полноправным участником международных транспортных перевозок в настоящее время.

Ключевые слова: транзитный потенциал, транспортные коридоры, евразийская интеграция, межАународная торговля.
\end{abstract}

\section{Introduction}

The purpose of this article is to study and describe the new features in the development of the transit potential of Kazakhstan in terms of globalization.

In order to successful development of the economy all countries have to develop market infrastructure. Market infrastructure includes a system of companies and organizations (banks, stock exchanges, transport, logistics, insurance companies, consulting and marketing firms, etc.) which provide the free movement of goods and services on the market [1]. Market infrastructure is a set of elements, institutions and services that create conditions for effective economic functioning of the market. Market infrastructure is a system of enterprises and organizations that provide movement of goods and services, money, securities, etc. [2]. The most important elements of market infrastructure are the transport and logistics system and transit potential of the country. Economic growth is always accompanied by the rapid growth of the system of transport, forwarding and logistic services. For successful integration into the global economy Kazakhstan should modernize transport and logistics infrastructure, develop transport corridors and realize transit potential.

«Efficient transportation is a key to competitiveness in foreign trade. A backward transportation network is incompatible with the needs of an industrially advanced economy. The quality and sophistication of a country's transportation infrastructure is one of the strongest indicators of its economic development» [3].

Transit potential is the most powerful instrument of realization of possibilities of country to provide and support international transport streams between different regions. In a number of the states of the world, such as Austria, Holland, Singapore and other transit is the considerable source of income and play 
a significant role in development of economy of the country. Nevertheless, the availability of transit potential does not yet guarantee a country receiving benefits. A large number of countries have a transit potential, but there are significant differences in its implementation. Usually, a transit state is understood as a country where the territory of which legitimate transit traffic is performed with direct or indirect participation [4].

Infrastructure is the physical components of the transport system that occupy a fixed position in space and create a transport network that includes connections (segments of roads and railways, pipelines, etc.) and nodes (intersections of road segments, terminals for various purposes). The movement of vehicles along the transport network forms traffic flows [5].

Many books and articles deal with the opinion that the geographical location of the region and the potential of its transport links make it possible to be a transcontinental bridge between east and west (Asia and Europe) [6], as well as the north and south (from the Indian Ocean and the Persian Gulf to Russia and the Baltic countries), implementing the concept of the Eurasian land bridge traffic, which is especially important in view of the congestion of ports and the increased flow of material goods from Asia to Europe [7]. Johannes F. Linn [8] also considers that Central Asia lies in the heart of the Eurasian continental space, where Eurasia is defined as covering all of Europe and Asia, including the Middle East and the Arab Peninsula. S. Frederick Starr and Svante E. Cornell [9] suggest in their article that a number of steps can be taken to further the development of continental transport system. A key question is the placement of logistics hubs in the region. Kazakhstan has considerable potential.

Central Asian countries have made a major effort to diversify their transport routes and energy links (especially through pipelines) and to connect their economies not only with the Russian Federation, but also with the EU and other neighbors. Automobile and railway transport infrastructure development is coordinated regionally under the auspices of the Central Asia Regional Economic Cooperation (CAREC) program [10].

Kazakhstan has an advantageous geographical location on the joint of two parts of the world Europe and Asia - is a valuable strategic resource, able to give an opportunity to a full degree to realize the transit potential, provide effective integration of country in the world economy system and to put up the same the economy of country on a new level to the country. Republic of Kazakhstan is the largest country, not having outlets to the sea. The role of Kazakhstan at the present stage of the country's development is predetermined by its transit position between Europe and Asia, the volume of trade turnover, which exceed 1 trillion USD, where China accounts for $50 \%$ of turnover [11]. Therefore, it is necessary to interest foreign freight forwarders to transport goods through the territory of Kazakhstan. Realization of transit potential is one of priority directions of economic politics of Kazakhstan. The government programs are aimed at forming of effective ways of the use of transit potential of country: The Strategy 2050, The Strategic plan of development of Republic of Kazakhstan 2020 [12], Government program of development and integration of infrastructure of a transport system Republics of Kazakhstan 2020, Transport strategy of Republic of Kazakhstan 2020 [13].

\section{Methodology}

In alignment with the aims of the paper, the authors apply three main methodological tools:

1) In order to draw a picture of the background of recent actions regarding freight transport on railway and on road, we analysed mainly the publications and government documents of the last decade. These scientific papers and the documents of different projects have given insight in the international research results and they also have provided us with the necessary information about situation in Kazakhstan.

2) The last part of the paper is gives detailed introducing and analyzing the present role that Kazakhstan is playing and might play in the future as a transcontinental bridge.

3) The situation, plans and actions are analysed from the perspective of their relevance for the Eurasian Economic Union and China, as a major trade partners.

The authors used the following research methods: from simple to complex; from the abstract to the concrete; the unity of historical and logical components; methods of statistical and economic analysis, comparative analysis, methods of dialectical cognition, etc. The construction and modernization of the infrastructure under the State Program of the Development and Integration of the Infrastructure of the Transport System of the Republic of Kazakhstan until 2020 largely focuses on increasing transit from China and integrally fits into the draft of the Economic Silk Road Belt (EKSP). The initiative of the EEPS project was put forward by the Chairman of the People's Republic of China, Xi Jin Pin, during 
his business trip to Kazakhstan in 2013. According to the project plan, the solution of China's domestic problems remains the first place for the Chinese leadership, and foreign policy is directly linked and built according to «internal» tasks [14].

\section{Results}

Perspective directions of realization of transit potential for Kazakhstan: through Russia in countries of EU; in China, Japan, countries of Southeast Asia; through the countries of Central Asia and Transcaucasia to Iran and Turkey.There are transport corridors on each of these directions, both on surface and on water ways. New transport routes are also developed. The special meaningfulness in PK is possessed by two transport knots is a railway mountain pass Dostyk-Alashankou on east of country and marine port of Aktau on a west. Transit through Kazakhstan has following advantages:

- Reduce speed and distance from the producer to the consumer from Asia to Europe. In contrast to the sea route in this area, where the cargo is in the path of 35-40 days, the delivery time is reduced by land 2-3 times.

- A stable political situation and a favorable investment climate in the country.

- Development of the EAEC will create a single customs border between China and the EU, facilitate customs clearance procedures.

Currently, trade between the EU and China is gaining a great pace, turnover which currently stands at more than $500 \mathrm{bln}$. Dollars. Kazakhstan intends to get a considerable profit from the transit of goods and increase the share of the traffic flow between them from $1 \%$ to $8 \%$ by 2020 . Needed modernization of the transport infrastructure in accordance with international standards and requirements. Impulse increase transit through Kazakhstan should make the construction and launch of the promising infrastructure projects: «Western Europe - Western China», which connects Asia and Europe; Railway «Uzen - Bereket - Gorgan», it allows you to cut the route of transit trains in the direction of «North South» at $600 \mathrm{~km}$ and open to Kazakh direct overland access to the Persian Gulf. Kazakhstan's participation in the Chinese Silk project will increase the volume of transit traffic.

In Kazakhstan there are problems hindering the development of transit:

- The low level of transport infrastructure, where there is a significant deterioration of its facilities from 40 to $100 \%$;
- The number of days required for registration of export and import procedures, the high degree of bureaucracy;

- Slow introduction of modern transport technologies;

- The poor state of roads;

- Underdeveloped and inefficient transport logistics, which contributes to higher prices of transportation and price of products.

Currently, the transit potential of Kazakhstan is not fully utilized. The majority of cargo is carried out within the country, and the volume of transit traffic is negligible. Today, international transit development has less to do with the peculiarities of the geographical location of the country, but with the introduction of new technologies, processes of unification and concentration in the world transport system. Transit potential can be regarded as one of the main strategic resources of the country. Its efficiency has a positive effect on the economy, making it an attractive investment. Rapidly growing economy of China and its main trading partner, the European Union created the preconditions for the development of transit and export-import opportunities of Kazakhstan. Active trade and economic relations between the countries of South-East, South and East Asia and European countries allow the use of transport communications in Central Asia, as well as to create an alternative land route as opposed to the Trans-Siberian Railway and the South Sea ways. Transit flows in the direction of South-Eastern and Eastern Asia - Europe is estimated at about 330 400 billion USD, up to $20 \%$ of these flows can pass through Kazakhstan [15].

The new Silk Road project in the long term is seen as a competitor to the sea route from SouthEast Asia to Europe. In the future, it is expected to increase the transit of oil and gas in the Chinese direction. Basically, the gas transit through Kazakhstan is carried out by four pipelines:

1. «Central Asia - Center» in the direction of Uzbekistan-Kazakhstan Russia (transported Turkmen and Uzbek gas);

2. «Bukhara gas - Tashkent - Bishkek - Almaty» in the direction of Uzbekistan - Kazakhstan (Uzbek gas transported);

3. «Orenburg - Novopskov» and MG «Union» in the direction of Russia (Russian gas);

4. «Bukhara - Ural» in the direction of Russia (Turkmen gas) [16].

As for the transit of oil through the territory of Kazakhstan, it is carried out by the following two oil pipelines: By pipeline «Atasu - Alashankou» and the pipeline «Tuymazy - Omsk - Novosibirsk-2». 
Today, through the territory of Kazakhstan there are 5 international transport corridors:

1. Northern Corridor of Trans-Asian Railway Main (TARM): Western Europe - China, Korean Peninsula and Japan through Russia and Kazakhstan;

2. Southern Corridor of TARM: South-Eastern Europe - China and South-East Asia through Turkey, Iran, Central Asian countries and Kazakhstan;

3. TRACECA: Eastern Europe - Central Asia via the Black Sea, Caucasus and the Caspian Sea;

4. North-South: Northern Europe - Gulf States via Russia and Iran with the participation of Kazakhstan.

5. The Central Corridor of TARM, which is most in demand at the regional transit.

Land transport corridors can reduce freight delivery time by reducing the distance in East-West. Through Kazakhstan there are 5 international automobile routes, with a total length of 23 thousand $\mathrm{km}$ :

1. Almaty - Astana - Kostanay (route M-36) with access to Chelyabinsk;

2. Almaty - Petropavlovsk with access to Omsk;

3. Almaty-Semey-Pavlodar (route M-38) with access to Omsk;

4. Almaty - Shymkent (route M-39) with access to Tashkent;

5. Shymkent - Aktobe - Uralsk (route M-32) with access to Samara [17].

\section{Discussion}

One of the biggest projects in the region road corridor «Western Europe - Western China». Implementation of the project began in the country in 2009, and completion is scheduled for 2016, this road corridor will provide the shortest way for Chinese goods in the countries of Western Europe, reverse deliveries to China of machinery and equipment, it will reduce the delivery time of goods between the EU and China 3, 5 times. This project is important for the development of business, tourism, trade, finance of Kazakhstan [18].

In the railway sector of the country there are two international transport corridors «Khorgos / Altynkol - Zhetygen station» and «Uzen - Bereket - Gorgan», which have been completed and put into operation [19]. Aktau is the only sea port in Kazakhstan. Recruited by one of the world's largest port operator DP World (Dubai Port World) for the management of FEZ «Khorgos» and its integration with the sea port of Aktau. In 2009 year due to loans in the transport sector of Kazakhstan directed to US $\$ 4.2$ bln. dollars. In 2010, the share of investment in transport from the total volume of investments in fixed assets amounted to $15.8 \%$, and the growth of investments already up to $19 \%$ was recorded in 2012 . The increase in the volume of transit traffic through the country EAEC will contribute to the creation of a unified transport and logistics companies (OTLK). OTLK was registered in November 2014 with the participation of three shareholders: «Russian Railways» (RZD) (share in the authorized capital of 99.84\%), Public Association «Belarusian Railways» (BC) $(0.08 \%)$ and JSC «National company» Kazakhstan Temir Zholy «(KTZ) (0.08\%) [20]. OTLK - a railway operator with infrastructure assets of the three countries, providing services for the organization of railway transportation and freight forwarding services.

OTLK aimed freight service between the countries of South-Eastern EU countries through the territory of the EAEC and is committed to a reorientation of container cargo from sea to rail. It is expected that by 2020 the volume of cargo from China through Kazakhstan in the framework of OTLK reach 1.7 million. Containers [21]. In Kazakhstan relevant question the competitiveness of land transport corridors. The advantage of an overland route to the speed of delivery of cargo by rail or road, which is 2.5 times less than for shipment by sea vessels. In assessing the competitiveness of a route you need to rely on well-known in transit «commercial triangle» - «time - the service - the tariff» [22].

Proximity to the EAEC Xinjiang, which produces oil, gas, coal, grown cotton, fruits and vegetables, has a number of advantages. Average annual volume of traffic between Europe and Asia by 2020, experts predict at least at the level of 800 million. Tons. But for the development of this volume lacks about 330 logistics centers with an annual capacity of 2-2.5 million each. Tons [23]. The deterioration of relations with Russia west led to the reorientation of the Russian Federation on trade in the direction of the east (Russia, China, Russia, Iran) and even greater relevance of the Eurasian integration project. In view of the transit through Kazakhstan will be in demand. Kazakhstan is important to actively develop trade with Iran and become a mediator in the Russian-Iranian trade.

Expansion of cooperation between Russia and China is gaining momentum and the two countries planned grandiose projects, for example, «Gazprom» plans to supply gas to China via two routes: the east (on the gas pipeline «Power of Siberia») and west (the gas pipeline «Altai»). Relations between Kazakhstan and Belarus in the field of transit considerably improved with the creation of the 
Customs Union and the EAEC. Parliament of the Republic of Kazakhstan in December 2014 was made on the establishment of the free passage of vehicles for the transport of goods between Kazakhstan and Belarus, as well as transit through their territories. This will allow the Kazakh carrier unhindered transportation of goods through the territory of Belarus in the EU.

Kyrgyzstan plans create Transkyrgyz highway Chu-FV, which connects north and south of the country, but this project is expensive and complicated. Kyrgyzstan will be able to build it with the EAEC with the support of Russia and Kazakhstan (from «East-West»), and China (the route «North-South»). Armenia does not have borders with other members of the union, its economy is linked to the Russian Federation, but it is necessary to establish relations with other members of the EAEC. Kazakhstan, Armenia can be considered as a partner in the South Caucasus in the context of its neighborhood with Georgia. The main trade partners of Kazakhstan are China and European Union, which help our country realize its transit potential. One of the main transport corridors of Kazakhstan and the entire northern corridor remains EAEC (China - Kazakhstan Russian Federation), the Trans-Asian Railway, which goes to the Trans-Siberian and BAM. And create Highway «Western Europe - Western China», which is considered in the context of the northern route of the Silk Road Economic Belt.

The project «One Belt and One Road» covers a large part of Eurasia, linking developing and developed countries. On the territory of this largescale project focused rich resource reserves, 63\% of the world population live and hypothetical economic scale -21 bln. US dollars. Members of the EAEC and China within Silk Road Economic Belt can cooperate in the modernization of transport infrastructure, in the field of construction, energy, resource extraction, and high technology. Transit corridor from China to Europe in the framework of Silk Road Economic Belt can be divided into three groups: the Northern Way (land «economic belt»), sea route («Marine Silk Road») and the Southern way.

North path includes routes that pass through the territory of China, Kazakhstan and Russia. One of them is the road corridor «Western Europe - Western China», which in China has paved its part. Another route goes in the direction of Urumqi -Dostyk - Omsk - Moscow - country EU. Sea path of Silk Road Economic Belt includes routes through Kazakhstan with access to the Caspian and Black Seas. The southern route includes the following routes: the first from Urumqi through the port of Aktau and further to the EU, while using Georgian ports; second from Urumqi through Kazakhstan and Central Asia to Iran and Turkey.

\section{Conclusion}

Transit opportunities of Kazakhstan can be used in all directions. The transport complex of the country is represented by all modes of transport: rail, road, pipeline, as well as water and air. The largest number of cargo transportation in Kazakhstan is carried out by rail. The main mode of transport in Kazakhstan is the railway transport, which accounts for $44 \%$ of total turnover [24].

Kazakhstan should use their geographical features: the central position in the Eurasian region and proximity to China. The formation of the republic as a transit hub must be accompanied by the development of a wide network of transport and logistics centers (TLC) with the strategic allocation in each of the regions of the country (in the west the seaport of Aktau, in the south - Almaty, in the north - Astana, in the east of the FEZ «Khorgos»). Availability branched TLC in Kazakhstan will increase the efficiency of rolling stock, improve the quality of transport, reduce transportation and logistics costs. When assessing the competitiveness of a particular route, it is necessary to rely on the «commercial triangle» - «time-service-tariff», which is well known in transit traffic [22].

The transit potential of Kazakhstan in the provision of alternative land routes from Asia to Europe and back. Advantages of overland routes data through the territory of the Republic of Kazakhstan: variation directions transit cargo flows to the EU - through Russia, through the countries of the Caucasus and in Central Asian countries and Iran; delivery speed and reduce the length of the distance compared to the sea route; a customs border between China and the EU as a result of the formation of the EAEC; the functioning of the existing international transport corridors passing through the territory of Kazakhstan.

Transportation infrastructure in Kazakhstan lags behind in the use of modern transport technologies and calls for technological upgrading. Full use of transport and transit potential of Kazakhstan will contribute to the following factors: a reduction in transport costs, the union of transit capabilities of all countries of the Union, de-bureaucratization of transport procedures, the development of logistics base, the ability to have equal access to Russian pipelines and ports in the Baltic Sea. 


\section{Литература}

1 Безгина М.В. (2011) Рыночная инфраструктура: понятие, функции и элементы. // Режим доступа: http://jurnal.org/ articles/2011/ekon21.html.

2 Современная экономика. (2015) Рыночная инфраструктура. // Режим доступа: http://econominfo.ru/view-article. php?id=31

3 Prentice, В. E. (2016). Concepts of Transportation Economics. World Scientific Publishing Co.Pte.Ltd // Режим доступа: http://www.worldscientific.com/doi/pdf/10.1142/9789814656177_fmatter

4 Ткаченко Н.Ю. Концептуальные основы совершенствования стратегии развития транзитного потенциала Украины // Культура народов Причерноморья. - 2008. - №143. - С. 59-64.

5 Горев А.Э. Основы теории транспортных систем. - СПб: СПб ГАСУ, 2010. - 214 с.

6 A Study of the Asian Development Bank Institute. Connecting Central Asia with Economic Centres : Final report (2014)// Режим доступа: https://www.adb.org/sites/default/files/publication/159307/adbi-connecting-central-asia-economic-centers-finalreport.pdf

7 Romanov M.; Romanova I. (2015) About Eurasian Transcontinental Transport Corridors and Economic Axes. Mediterranean Journal of Social Sciences, 6 (5 S2).//Режим доступа: http://www.mcser.org/journal/index.php/mjss/article/viewFile/7649/7330

8 Linn J.(2012) Central Asian Regional Integration and cooperation : Reality or Mirage. THE ECONOMICS OF THE POSTSOVIET AND EURASIAN INTEGRATION// Режим доступа: https://www.brookings.edu/wp-content/uploads/2016/06/10-regional-integration-and-cooperation-linn.pdf

9 Starr, S. F.; Cornell S.E. (2015). The EU and Central Asia: Developing Transport and Trade. Analytical Articles//Pежим доступа: https://www.silkroadstudies.org/resources/pdf/SilkRoadPapers/2015_12_SRP_Transport.pdf

10 Asian Development Bank (2009). : Transport and trade logistics development strategies for CAREC.// Режим доступа: https://www.adb.org/sites/default/files/institutional- document

11 В странах АТЭС недовольны РЖД // РБК Ежедневная деловая газета. - Режим доступа: http://www.rbcdaily.ru/politics/562949983921420.

12 Стратегия «Казахстан-2050». Стратегический план развития Республики Казахстан до 2020 года. //Режим доступа: http://www.akorda.kz/ru/official_documents/strategies_and_programs

13 Транспортная стратегия Республики Казахстан до 2020 года. Паспорт Стратегии. // Режим доступа: http://adilet.zan. $\mathrm{kz} /$ rus/docs/P050000075

14 К Великому океану -3 «Экономический пояс Шелкового пути» и приоритеты совместного развития евразийских государств // Аналитический доклад Международного Дискуссионного клуба «Валдай» // Режим доступа: http://ru.valdaiclub. com/a/reports/k-velikomu-okeanu-3/.

15 Бутырина Н. Интеграция Казахстана в мировую транспортную систему // Вестник КазАТК. - 2013. - №6 (85).

16 Мазаренко Д. (2014) Сколько Казахстан зарабатывает на транзите нефти и газа //http://vlast.kz/article/skolko_kazahstan_zarabatyvaet_na_tranzite_gaza_i_nefti

17 Можарова В.В. (2011) Транспорт в Казахстане: современная ситуация, проблемы и перспективы развития. - Алматы: КИСИ при Президенте РК, 2011. - 216 с.

18 Трансконтинентальный коридор «Западная Европа - Западный Китай» - новый путь в Европу: от мечты к реальности // Режим доступа:http://www.europe-china.kz/info/69.

19 Хронология важнейших событий, связанных со строительством железной дороги Узень - Туркменистан - Иран // Қазақстан темір жолы. - Режим доступа: http://www.railways.kz/ru/node/7913.

20 Объединенная транспортно-логистическая компания ОТЛК //http://www.utlc.com/o-kompanii/ (20.06.2013).

21 Ионова Е.П. Транзитный потенциал Казахстана // Россия и новые государства Евразии. - 2014. - №1 - С. 68-73.

22 Винокуров Е.Ю., Джадралиев М.А., Щербанин Ю.А. Международные транспортные коридоры ЕврАзЭС: быстрее, дешевле, больше // Отраслевой Обзор ЕАБР. - Алматы: ЕАБР, 2009. - № 5. - 60 с.

23 Евразийский экономический союз взялся за транзит // «Российская Газета»: Спецвыпуск «Транспорт и логистика». - 2015. - №6655 (84).

24 Кузьмина Е.М. Развитие транспорта в Казахстане // В сб.: Транспорт и связь в новых независимых государствах: особенности и факторы развития. - М.: ИЭ РАН, 2013. - С. 69-88.

\section{References}

1 A Study of the Asian Development Bank Institute. Connecting Central Asia with Economic Centres: Final report (2014)// Retrieved from: https:/www.adb.org/sites/default/files/publication/159307/adbi-connecting-central-asia-economic-centers-finalreport.pdf

2 Asian Development Bank (2009). : Transport and trade logistics development stradegies for CAREC.// Retrieved from : https://www.adb.org/sites/default/files/institutional- document

3 Bezgina M.V. (2011) Rynochnaya infrastruktura: ponyatie, funkcii i elementy. (Market infrastructure: concept, functions and elements)// Retrieved from: http://jurnal.org/articles/2011/ekon21.html.

4 Butyrina N. (2013) Integratsiya Kazakhstana v mirovuyu transportnuyu sistemy (Integration of Kazakhstan into the world transport system) // Vestnik KazATK.- №6 (85). 
5 Evraziyskiy economicheskiy souz vzyalsa za transit (2015) (The Eurasian Economic Union took up transit)// Rossiyskaya gazeta»: Spets vypusk «Transport I logistika». - №6655 (84).

6 Gorev A.E. (2010) Osnovy teorii transportnykh system. (Fundamentals of the theory of transport systems) $-\mathrm{SPb}: \mathrm{SPb}$ GASU. $-214 \mathrm{~s}$.

7 Ionova E.P.(2014) Tranzitnyi potentsial Kazakhstana (Transit potential of Kazakhstan) // Rossia I novie gosudarstva Evrazii. - №1. - C. 68-73.

8 K Velikomu okeanu - 3 «Ekonomicheskyi Poyas Shelkovogo Puti» I prioritety sovmestnogo razvitia evraziyiskih gosudarstv (2017) (To the Great Ocean-3 «The Economic belt of the Silk Road» and priorities for the joint development of Eurasian states) // doklad mezhdunarodnogo diskussionnogo kluba «Valday» // Retrieved from: http://ru.valdaiclub.com/a/reports/k-velikomu-okeanu-3/.

9 Khronologia vazhyeishih sobytyi, svasannyh s stroitelstvom zheleznoi dorogi Uzen - Turkmenistan - Iran (2013) (Chronology of the most important events connected with the construction of the Uzen-Turkmenistan-Iran railway)// KTZH. - // Retrieved from: http://www.railways.kz/ru/node/7913.

10 Kuzmina E.M. (2013) Razvitie transporta v Kazakhstane (Transport development in Kazakhstan) // Sb.: Transport I svyas v SNG: osobennosty I factory razvitia. - M: IE RAN. - S. 69-88.

11 Linn J.(2012) Central Asian Regional Integration and cooperation : Reality or Mirage. THE ECONOMICS OF THE POSTSOVIET AND EURASIAN INTEGRATION// Retrieved from: https://www.brookings.edu/wp-content/uploads/2016/06/10-regional-integration-and-cooperation-linn.pdf

12 Mazarenko D. (2014) Skolko zarabatyvaet Kazakhstan na tranzite nefti I gaza (How much does Kazakhstan earn on transit of oil and gas)// Retrieved from http://vlast.kz/article/skolko_kazahstan_zarabatyvaet_na_tranzite_gaza_i_nefti

13 Mozharova V.V. (2011) Transport v Kazakhstane: sovremennaya situatsia, problemy I perspektivy razvitia. (Transport in Kazakhstan: current situation, problems and development prospects) - Almaty: KISI. -216 c.

14 Obidenennaya transportno - logosticheskaya kompania OTLK (2013) (United Transport and Logistics Company OTLK) // Retrieved from: http://www.utlc.com/o-kompanii

15 Prentice, B. E. (2016). Concepts of Transportation Economics. World Scientific Publishing Co.Pte.Ltd// Retrieved from: http://www.worldscientific.com/doi/pdf/10.1142/9789814656177_fmatter

16 Romanov M.; Romanova I. (2015) About Eurasian Transcontinental Transport Corridors and Economic Axes. Mediterranean Journal of Social Sciences, 6 (5 S2)// Retrieved from: http://www.mcser.org/journal/index.php/mjss/article/viewFile/7649/7330

17 Sovremennaya ekonomika. (2015) Rynochnaya infrastruktura. (Modern economy. Market infrastructure)// Retrieved from : http://econominfo.ru/view-article.php?id=31

18 Starr, S. F.; Cornell S.E. (2015). The EU and Central Asia: Developing Transport and Trade. Analytical Articles// Retrieved from: https://www.silkroadstudies.org/resources/pdf/SilkRoadPapers/2015_12_SRP_Transport.pdf

19 Strategia «Kazakhstan-2050». (2012) Strategicheskyi plan razvitia RK do 2020 goda (Strategy «Kazakhstan-2050». Strategic Development Plan of the Republic of Kazakhstan until 2020)// Retrieved from: http:/www.akorda.kz/ru/official_documents/ strategies_and_program

20 Tkachenko N.U. (2008) Konceptualnye osnovy sovershenstvovania strategii razvitia tranzitnogo potenciala Ukrainy (Conceptual framework for improving the strategy for developing the transit potential of Ukraine) // Kultura narodov Prichernomoria. - №143.-S.59-64.

21 Transkontinentalnyi koridor «Zapadnaya Evropa - Zapadnyi Kitay» - novyi put v Evropu: ot mechty k realnosty (2015) (The transcontinental corridor «Western Europe - Western China» - a new way to Europe: from dream to reality) // Retrieved from: http: www.europe-china.kz/info/69.

22 Transportaya Strategia RK do 2020 goda. (2005) (Transport strategy of the Republic of Kazakhstan until 2020)// Retrieved from: http://adilet.zan.kz/rus/docs/P050000075

23 V stranah ATES ne dovolny RZHD (In APEC countries are dissatisfied RZD) (2015)// RBK Ezhednevnaya delovaya gazeta// Retrieved from: http://www.rbcdaily.ru/politics/562949983921420.

24 Vinokurov E.U., Dzhadraliev M.A., Sherbanin U.A. (2009) Mezhdunarodnie transportnye koridory EvrAzEs: bystree, deshevle, bolshe (International transport corridors of EurAsEC: faster, cheaper, more)// Otraslevoy obzor EABR. - Almaty: EAБP. №5. $-60 \mathrm{c}$. 